\title{
Study of pathogenicity and severity of Lactococcus garvieae isolated from rainbow trout (Oncorhynchus mykiss) farms in Kohkilooieh and Boyerahmad province
}

Esmaeil Karami ${ }^{1}$, Mojtaba Alishahi ${ }^{1}$, Taravat Molayemraftar ${ }^{1 *}$, Masoud Ghorbanpour $^{2}$, Mohammad Reza Tabandeh ${ }^{3}$ and Takavar Mohammadian ${ }^{1}$

\begin{abstract}
Background: Lactococcus garvieae is one of the most important risk factors in the rainbow trout culture. Therefore, the purpose of this study was to identify and detect strains isolated from rainbow trout suspected of having Lactococcus garvieae using biochemical characteristics and PCR and determination of the degree of severity of isolated strains.

Methods: In this study, the cause of lactococcosis in selected rainbow trout farms in Kohkilooieh and Boyerahmad province was assayed. Gram-positive and catalase-negative bacterial isolates were first obtained from selected trout fish farms using conventional biochemical tests and PCR assay. The 10-day LD 50 method (concentration causing $50 \%$ mortality in 10 days) was used to determine the severity of the isolated bacteria.

Results: One bacterial isolate was detected from all sampled fish which confirmed as Lactococcus garvieae using a specific PCR assay based on the 16S rDNA gene by producing a single band of $1107 \mathrm{bp}$. Analysis of the rate of mortality showed that the 10-day $L_{50}$ was $4.6 \times 10^{5} \mathrm{CFU} /$ fish. The results of this study showed that isolated bacteria had high severity for rainbow trout. The presence of bacteria in internal organs of suspected fish showed a severe systemic infection in challenged fish. Antibiogram assay also indicated that the isolated Lactococcus garvieae were resistant to some mostly used antibiotics in rainbow trout.

Conclusions: According to current research, it can be concluded that the condition of lactococcosis in the studied area is not suitable, and despite the presence of disease, there is no proper action to control and prevent the disease. Unfortunately, isolated bacteria from the studied area have a very high severity compared to bacteria isolated from other regions of the country or other countries. Therefore, further investigation is needed to determine the cause of this difference and possibly in the design of the vaccine.
\end{abstract}

Keywords: Rainbow trout, Pathogenicity, Lactococcus garvieae, $\mathrm{LD}_{50}$

\footnotetext{
*Correspondence: Taravat.Molayemraftar@yahoo.com

1 Department of Clinical Sciences, Faculty of Veterinary Medicine, Shahid

Chamran University of Ahvaz, Ahvaz, Iran

Full list of author information is available at the end of the article
}

(c) The Author(s). 2019 Open Access This article is distributed under the terms of the Creative Commons Attribution 4.0 International License (http://creativecommons.org/licenses/by/4.0/), which permits unrestricted use, distribution, and reproduction in any medium, provided you give appropriate credit to the original author(s) and the source, provide a link to the Creative Commons license, and indicate if changes were made. The Creative Commons Public Domain Dedication waiver (http://creativecommons.org/publicdomain/zero/1.0/) applies to the data made available in this article, unless otherwise stated. 


\section{Background}

Lactococcus garvieae is a gram-positive and non-moving bacteria, and pathogen of lactococcosis, and affects much wild and cultured fish; it is an emerging zoonotic pathogen that causes serious infections in humans and animals (Vendrell et al. 2006). Lactococcosis is a systemic disease in marine fish including tilapia, sea bass, eel, and yellowfish and is now recognized as one of the most important diseases of the rainbow trout in aquaculture (Austin and Austin 2007, 2016; Meyburgh et al. 2017; Chapela et al. 2018). Several reports are presented of lactococcosis occurrence in marine fish, brackish water, and freshwater, especially when water temperature increases over $15^{\circ} \mathrm{C}$ (Austin and Austin, 2007). The first occurrence of lactococcosis in rainbow trout was reported in Spain in 1988 (Ghittino and Prearo 1992). This pathogen has caused serious economic losses in the cultivation of marine and freshwater fishes (Vendrell et al. 2006; Wang et al. 2007; López et al. 2015; Meyburgh et al. 2017). Farming rainbow trout fish has been developed during the last decades in different suitable areas of Iran, but unfortunately, some diseases and health problems such as lactococcosis have caused a lot of damage to the fish culture industry and damages to tens of millions per year (Soltani et al. 2016). The L. garvieae was first isolated in Iran from a rainbow trout farm in Fars province (Soltani et al. 2005). The incidence of lactococcosis in Iran is mainly in the livestock stage, which may cause damage to fish farms between 5 and 75\%, and the major losses occur in the fattening stages, so the damages are significant and the agents of this disease can also be transmitted to humans causing endocarditis, cholecystitis, and diskospondylitis, so the human health debate can also be important (Wang et al. 2007; Chan et al. 2011; Kim et al. 2013; Soltani et al. 2015; Gauthier 2015; Meyburgh et al. 2017). Environmental factors, hosts, and pathogens play a role in the development and spread of this disease in rainbow trout farms, so attention to bacterial strains of the disease and its various reservoirs is very important in controlling the disease and preventing it (Soltani et al. 2009). Considering that L. garvieae is the primary cause of mortality and risk factor in the rainbow trout culture industry during hot seasons; therefore, the purpose of this study was to identify and detect strains isolated from rainbow trout suspected of having L. garvieae using biochemical characteristics and PCR and determination of the degree of severity of isolated strains.

\section{Methods}

\section{Sample collection}

During the fall of 2014, the bacterial strains of L. garvieae were obtained from suspected fish of Koohdasht, Kohkilooieh, and Boyerahmad province, the southwest of Iran. A total of 30 rainbow trouts with a weight range of 100-200 g were collected from suspicious farms. Suspect fish were transferred to the laboratory of the Department of Aquatic Animal Health, Faculty of Veterinary Medicine, Shahid Chamran University of Ahvaz, alive.

\section{Bacterial isolation and culturing}

Bacterial culture was performed on suspected fish with symptoms of hemorrhage, exophthalmia, septicemia, and melanosis. The kidney and brain samples were streaked onto sterile conditions on blood agar (Merck, Darmstadt, Germany) and trypticase soy agar (TSB, Biokar Diagnostics, Zac de Ther, France) medium, and incubated at $25^{\circ} \mathrm{C}$ for $48 \mathrm{~h}$. Single colonies from plates with pure culture growth were re-streaked on the BHIA (Brain Heart Infusion Agar; Merck, Darmstadt, Germany) medium to obtain pure isolates.

\section{Biochemical properties of isolated bacteria}

Gram-positive cocci and catalase-negative pure colonies were subjected to gram staining. The biochemical properties of the isolates were determined according to the method recommended by Austin and Austin (2007) and Soltani et al. (2005). Hemolysis test of sheep red blood cells was performed at 25 and $37^{\circ} \mathrm{C}$. The Lactococcus isolates were tested for bacterial growth potentials at different temperatures $\left(10,37\right.$, and $\left.45^{\circ} \mathrm{C}\right)$ and at different $\mathrm{pH}$ (5-5.9), catalase, oxidase, VP (Voges-Proskauer) reaction, hydrolysis, different sugar consumption, oxidation and fermentation of glucose $(\mathrm{o} / \mathrm{f})$, production of indole and $\mathrm{H}_{2} \mathrm{~S}$, and movement test in the SIM (sulfide-indole-motility; Merck, Darmstadt, Germany) medium. All of these tests were read after $24 \mathrm{~h}$ of incubation at $30^{\circ} \mathrm{C}$.

\section{PCR assay}

To confirm the diagnosis of the disease, sorbitol-positive isolates with similar characteristics of $L$. garvieae were used for PCR studies. For this, colony PCR was performed using an amplicon extraction kit (CinnaGen, Tehran, Iran) based on the kit's instructions, and the DNA quality extracted by electrophoresis (NanoDrop Spectrophotometer, SPX2, Eppendorf, Germany) on a $1.5 \%$ agarose gel (CinnaGen, Tehran, Iran) was investigated. PCR test was done based on the method recommended by Woodman (2008) using PLG-F (5-CATAAC AATGAGAATCGC-3) and PLG-R (5-GCACCCTCGC GGGTTG-3) primer sequences for amplification of $16 \mathrm{~S}$ rDNA sequence and observation of a band of $1100 \mathrm{bp}$. To perform the PCR reaction, $10 \mu \mathrm{l}$ of Master Mix (Amplicon kit) was added to the 0.2-ml microtube, followed by $0.5 \mu \mathrm{l}$ of each primer. Then, a pure colony of bacteria cultured with sterile applicator was poured into the microtube under sterile conditions, and $6 \mu \mathrm{l}$ distilled water was added to it. The PCR steps were performed using ThermoCycler machine (Eppendorf, USA) with 
initial denaturation for $5 \min \left(95^{\circ} \mathrm{C}\right)$, denaturation for 1 min $\left(94^{\circ} \mathrm{C}\right)$, annealing for $45 \mathrm{~s}\left(58^{\circ} \mathrm{C}\right)$, elongation for 1 $\min \left(72^{\circ} \mathrm{C}\right)$, then repeat steps $2-4$ to 30 cycles, and finally the final elongation step for $5 \mathrm{~min}\left(72^{\circ} \mathrm{C}\right)$. The PCR product was electrophoresed with agarose gel $1.5 \%$, and after staining with a safe stain (CinnaGen, Tehran, Iran), the gel was photographed using the Gel Documentation (Gel doc, 6454, Mina Tajhiz Pars, Iran).

\section{Test of microbial susceptibility to antibiotics}

The antibiotic test was used to determine the susceptibility of isolated bacteria from common antibiotics using standard disk diffusion (Bauer et al. 1966). For this purpose, antibiotics such as tetracycline, streptomycin, enrofloxacin, ciprofloxacin, lincospectin, and florfenicol were used. For this purpose, a bacterial concentration of 0.5 McFarland was prepared in a nutrient medium of Mueller-Hinton medium (Merck, Darmstadt, Germany) and then cultured on agar of Mueller-Hinton agar medium by the spread plate method which was cultured in five directions. Antibiotic disks were inserted at appropriate intervals. Plates were incubated at $37^{\circ} \mathrm{C}$ for $24 \mathrm{~h}$, and the inhibition halo diameters were measured.

\section{Investigation of severity (pathogenicity) of isolated bacteria in rainbow trout}

Due to the fact that all bacteria isolated from fish have the same biochemical and molecular properties and there was no difference in their biochemical and molecular methods, the source bacteria contamination was detected on one strain, and to determine the bacterial severity, the conventional $\mathrm{LD}_{50}$ method by the technique of Reed and Muench (1938) and Probit software were used as follows:

In short, after bacterial culture in TSB medium for $48 \mathrm{~h}$ at $25^{\circ} \mathrm{C}$, bacterial isolation was performed using a centrifuge at $3000 \mathrm{~g}$ for $15 \mathrm{~min}$. The isolated bacteria were washed with sterile PBS (phosphate-buffered saline; Merck, Darmstadt, Germany). Using McFarland tubes and control by viable colony count, dilutions were sequentially based on 10 (104 to 10). The selection of concentrations was determined based on the initial pilot test. After the adaptation of rainbow trout (average weight $30 \mathrm{~g}$ ) to culture conditions in the laboratory, the fish were infected with these dilutions. At first, fish of each treatment were anaesthetized by 2phenoxyethanol (Merck, Darmstadt, Germany) at a concentration of $400 \mathrm{ppm}$ in 1-1 water and then $0.1 \mathrm{ml}$ of each bacterial dilution injected intraperitoneally into 10 fishes in 3 replicates. To the control group, $0.1 \mathrm{ml}$ of sterile PBS was injected. After injections of bacterial dilutions, the number of casualties was recorded up to 10 days after injection. To ensure the cause of the death of fish, the culture was performed on the kidneys and brain of the fish, and the injected bacterium was re-isolated.

\section{Statistical method}

The results of the study of bacterial severity were evaluated using Reed and Muench's (1938) technique and Analysis Program Probit EPA software version 1.5. In this software, the medium lethal dose $\left(\mathrm{LD}_{50}\right)$ is determined in a given time with an error rate of less than 0.05 .

\section{Results}

\section{Bacterial isolation and culturing}

The water temperature was recorded at $17^{\circ} \mathrm{C}$ during the course of the disease. From the beginning of the mortality to the time of sampling (about a week), the proportion of mortality was close to $5 \%$ of the population. The sick fish showed behavioral symptoms including: lethargy, neglect, lack of nutrition, accumulation at the inlet and outlet, including irregular and sometimes rotational swiming and clinical signs of the disease including bilateral exophthalmia and hemorrhage in the eyes, darkening of the body color, cutaneous ulcers (in some cases) accompanied by bleeding in the dermal region of the abdominal and chest area, as well as anatomical symptoms including enlargement and color-change in the spleen, swelling, blurry and hemorrhage of the kidneys and the liver, increased abdominal fluid volume, and hemorrhages in visceral fats.

\section{Biochemical properties of isolated bacteria}

The bacterial culture results from the brain and kidney organs of the sick fish resulted in the isolation of non-moving gram-positive cocci and catalase-negative and oxidasenegative. These results were observed in almost all samples taken from different farms. The results of the sorbitol test showed that isolated strains were able to fertilize sorbitol glucose, which confirmed the L. garvieae species. Other results of biochemical properties of these isolates are presented in Table 1, so that in comparison with the properties of the isolates reported in the authoritative and official sources, all strains isolated from the fish are likely to have the same source and are classified in the Lactococcus garvieae species.

\section{Test of microbial susceptibility to antibiotics}

The results of the antibiogram test showed that the isolated L. garvieae species had the highest susceptibility to florfenicol and lincospectin antibiotics and had no sensitivity to tetracycline, streptomycin, enrofloxacin, and cyrofloxacin (Table 2).

\section{PCR assay}

Molecular study (PCR) was performed on all isolated strains that were gram-positive coccidia and catalasenegative and sorbitol-positive. The results show that the expected bands of $1107 \mathrm{bp}$ show 16s rDNA gene for $L$. garvieae in all isolates (9), which were ultimately confirmed by the detection of $L$. garvieae isolated from the sick fish (Fig. 1). 
Table 1 Biochemical characteristics of L. garvieae isolated from the rainbow trout in Kohkiluyeh and Boyerahmad province

\begin{tabular}{|c|c|c|c|}
\hline Characteristic & & Characteristic & \\
\hline Gram stain & + & Trisodium citrate & - \\
\hline Move & - & Arginine hydrolase & + \\
\hline Oxidase & - & Lysine decarboxylase & - \\
\hline Catalase & - & Production of $\mathrm{H} 2 \mathrm{~S}$ & - \\
\hline Andole & - & Hemolysis & Alpha \\
\hline Methyl red & + & Nitrite reduction & - \\
\hline Voges-Proskauer & - & Grow in NACL & \\
\hline TSI & $\mathrm{A} / \mathrm{A}-$ & $0 \%$ & + \\
\hline $\mathrm{O} / \mathrm{F}$ & $\mathrm{F}$ & $5 \%$ & + \\
\hline Hydrolysis & & $6.5 \%$ & + \\
\hline Gelatin & - & Grow at temperature & \\
\hline Urea & - & $10^{\circ} \mathrm{C}$ & \\
\hline Scolin & + & $37^{\circ} \mathrm{C}$ & + \\
\hline Consumption & & $45^{\circ} \mathrm{C}$ & + \\
\hline Glucose (filtered) & - & $\mathrm{pH}(5-9.5)$ & + \\
\hline Sucrose & + & & \\
\hline Sorbitol & + & & \\
\hline Lactose & + & & \\
\hline Mannitol & + & & \\
\hline Inositol & - & & \\
\hline Trehalose & + & & \\
\hline Xylose & - & & \\
\hline Maltose & + & & \\
\hline Salicin & - & & \\
\hline Raffinose & - & & \\
\hline Glycerol & - & & \\
\hline
\end{tabular}

$A / A-$ acid/acid no gas, $F$ fermentation, $v$ variable

\section{Investigation of severity (pathogenicity) of isolated bacteria in rainbow trout}

Considering the similarity of the strains examined and the probability of the disease spreading from a single source (possibly suspected fry fish), one of the isolates

Table 2 Sensitivity of L. garvieae isolated to different antibiotics

\begin{tabular}{lll}
\hline Antibiotics & $\begin{array}{l}\text { Active ingredient in } \\
\text { the disk }(\mathrm{mg})\end{array}$ & $\begin{array}{l}\text { Inhibition diameter }(\mathrm{cm}) \\
(\text { mean } \pm \mathrm{SE})\end{array}$ \\
\hline Florfenicol & 30 & $2.6 \pm 0.3$ \\
Lincospectin & 30 & $2.1 \pm 0.11$ \\
Gentamicin & 10 & $1.5 \pm 0.08$ \\
Tylosin & 30 & $1.5 \pm 0.4$ \\
Streptomycin & 10 & $0 \pm 0$ \\
Enrofloxacin & 5 & $0 \pm 0$ \\
Ciprofloxacin & 30 & $0 \pm 0$ \\
Tetracycline & 30 & $0 \pm 0$ \\
\hline
\end{tabular}

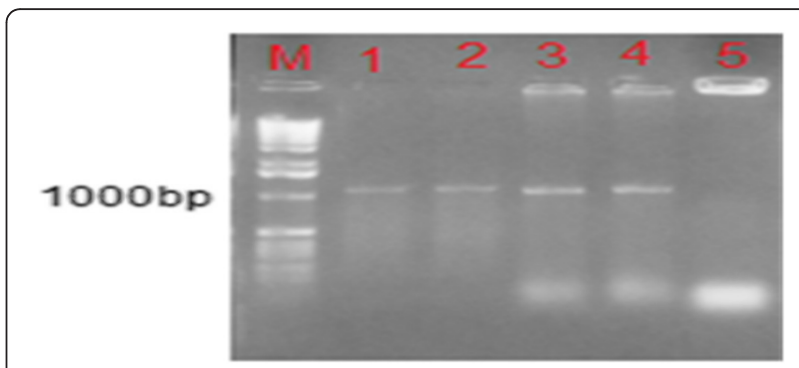

Fig. 1 Agarose gel 1.5\% related to the PCR product obtained from $L$. garvieae DNA isolated from the rainbow trout farms of Kohkiluyeh and Boyerahmad province. $M$, markers; $3-1$, samples of the isolates tested; 4, positive control (L. garvieae X54262); 5, negative control

from the farm with the highest mortality rates was used to check the severity. The results of the bacterial severity study based on cumulative mortality after bacterial contamination (challenge) and using the method of Reed and Muench (1938) are presented in Fig. 2 and Table 3. The $\mathrm{LD}_{50}$ of $7.4 \times 10^{5}$ was calculated using Probit software.

\section{Discussion}

Lactococcosis is a devastating disease in the culture of salmonids. The first occurrence of lactococcosis in rainbow trout was reported in Spain in 1988. Since then, lactococcosis has been causing severe casualties in cultured rainbow trout in many parts of the world including Spain, Iran, Australia, South Africa, Japan, Korea, USA, Taiwan, Greece, England, Italy, France Portugal, Turkey, and Bulgaria (Didinen et al. 2014; Raissy et al. 2018; Baños et al. 2019). This disease has been recognized as one of the major problems in the culture of cold-water fish in Iran, especially in the last two decades. In recent years, this disease has caused serious damage to the culture industry of rainbow trout in some provinces, according to reports (Akhlaghi and Keshavarzi 2002).

The L. garvieae was first isolated in Iran from a rainbow trout farm in Fars province. The reported symptoms include irregular swimming, black body color, hemorrhagic septicemia, ascites, bilateral exophthalmia, cataract, and hemorrhage in the liver, spleen, kidney, brain, and intestine, and mortality rates in the farms varied from 40 to $20 \%$ (Soltani et al. 2005). The registered clinical symptoms in this study were similar to the symptoms mentioned in other studies in Iran and other parts of the world (Ghittino and Prearo 1992; Prieta 1993; Eldar et al. 1999; Vendrell et al. 2004, 2006). In this study, the bacteria isolated from all samples were of the same origin and all biochemical and molecular characteristics were the same. Therefore, a type of bacteria likely caused the mortality in the studied farms. By examining the source of fish supply in selected farms, this possibility was confirmed, but due to the fish in the farms examined were supplied from different sources 


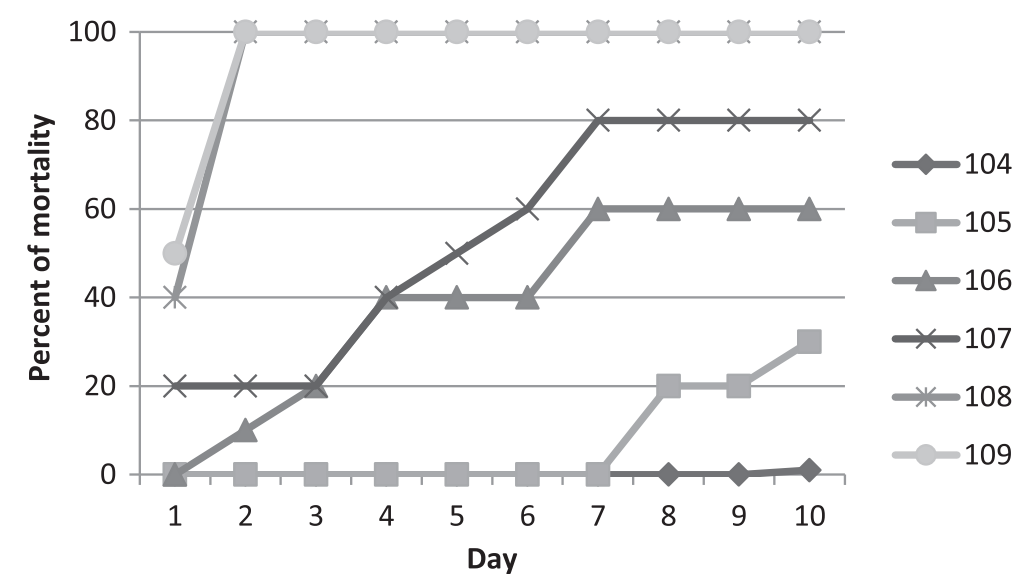

Fig 2 The $L D_{50}$ of $L$. garvieae isolated from rainbow trout

and at different periods, it cannot be safely identified as the main source of infection. On the other hand, it is possible that this strain overcame other strains of the region due to higher severity and could be maintained due to resistance to common antibiotics in the region. The biochemical characteristics of the isolated bacteria showed that the tested species were L. garvieae. Despite the high compliance with biochemical factors, the species was not consistent with the results of Austin and Austin (2007) in the Voges-Proskauer reaction and the consumption of saccharose and salicin sugars. But the results of the study were consistent with the results of Soltani et al. (2008) and Sharifiyazdi et al. (2010) in these indices which show the similarity of this strain with strains isolated from other regions of Iran. So it confirms the hypothesis that this strain may be considered as a dominant species due to high antibiotic resistance and a high level of resistance in different regions of the country.

Despite the possibility of infecting fry fish in the aquaculture farms, it cannot be described as the main cause. Failure to observe the principles of biosecurity in farms creates the possibility of horizontal transmission of infection from a farm to another farm by water, birds, workers, visitors, and aquaculture equipment. There are reports that at specific times, a specific bacterial isolate is spread over a large area and replaces old and low severity strains due to its high resistance and severity (Kim et al. 2004). However, this indicator should be

Table 3 Deadly concentrations of $L$. garvieae isolated from rainbow trout (CFU/ml)

\begin{tabular}{llll}
\hline Lethal dose & 10 days & Low range & Upper range \\
\hline $\mathrm{LC}_{10}$ & $1.2 \times 10^{4}$ & $3.84 \times 10^{4}$ & $6 \times 10^{4}$ \\
$\mathrm{LC}_{50}$ & $4.7 \times 10^{5}$ & $1.1 \times 10^{5}$ & $1.7 \times 10^{6}$ \\
$\mathrm{LC}_{75}$ & $3.1 \times 10^{6}$ & $9.4 \times 10^{5}$ & $2.3 \times 10^{7}$ \\
$\mathrm{LC}_{90}$ & $1.7 \times 10^{7}$ & $4.1 \times 10^{6}$ & $3.8 \times 10^{8}$ \\
\hline
\end{tabular}

taken into account in the fight against this disease in the region and the design of the appropriate control method. While biochemical properties are a common method for identifying L. garvieae, due to frequent errors in diagnosis, the usefulness of this method has been questioned. Therefore, the use of molecular techniques is a suitable method for accurate and rapid identification of bacterial strains (Roach et al. 2006). In this study, type-specific primers were used for the identification of bacteria and the results of the PCR product showed that all strains isolated from samples were L. garvieae and were quite similar.

The isolated $L$. garvieae from this study was sensitive to fluorophenicol, lincospectin, gentamicin, and tylosin; had the most sensitivity to fluorophenicol; and showed no sensitivity to tetracycline, enrofloxacin, streptomycin, and ciprofloxacin antibodies. These findings were consistent with the results of Ravelo et al. (2001). In a study by Soltani et al. (2008), isolated L. garvieae was only susceptible to enrofloxacin and ampicillin. Sharifiyazdi et al. (2010) reported that the isolated L. garvieae was sensitive to erythromycin, sulfadiazine, and chloramphenicol antibiotics. Today, fluorophenicol, oxytetracycline, and enrofloxin antibiotics are the most commonly used on farms. Due to the inappropriate use of tetracycline and some other antibiotics, the complete resistance to them in fish has been created, which is probably due to the gene's emergence of resistance to these antibiotics in pathogenic bacterial species. In a study by Kim et al. (2004), tet (S) and tet (M) resistant genes were found in L. garvieae isolated from fish. By examining the sampling sites, it was found that antibiotics that were found to be ineffective in the bacteria were used with high doses and prolonged periods of many occasions in the emergence of disease. It is possible that high resistance to these antibiotics is due to its high dosage and failure to complete treatment period and the unnecessary repetition of antibiotic therapy in the past years. On the other hand, the 
high sensitivity of $L$. garvieae to fluorophenicol confirms the value of this antibiotic in the fight against this disease, so the least resistance to this antibiotic in the pathogens was reported in the sources (Sharifiyazdi et al. 2010).

In this study, the $\mathrm{LD}_{50}$-isolated $L$. garvieae was determined to be $7.4 \times 105 \mathrm{CFU} / \mathrm{ml}$ after 10 days of the challenge, indicating a very high severity of these bacteria in rainbow trout. In the study of Sharifiyazdi et al. (2010), $\mathrm{LD}_{50}$ of isolated $L$. garvieae was also estimated to be $6 \times 105 \mathrm{CFU} / \mathrm{ml}$, which showed a lower severity than the current study. In a similar study, Chen et al. (2002) reported that L. garvieae with a concentration of $100 \times 108 \times 108$ resulted in $100 \%$ mortality and they reported a concentration of $1: 106 \times 1 \mathrm{CFU} / \mathrm{ml}$ as the $\mathrm{LD}_{50}$ of this bacterium in Mullet. Türe et al. (2014) estimated the $\mathrm{LD}_{50}$ of $L$. garvieae isolated from rainbow trout by $105 \times 1.7 \mathrm{CFU} / \mathrm{ml}$, which is a higher severity of bacteria in the present study. Lactococcosis is recognized as an acute septicemia disease, the clinical signs of this which are very similar in many species (Chen et al. 2002). Water temperature is an important factor in the spread of disease, and it has been reported that increasing the temperature during the summer months causes the severity of the disease to increases. Although the disease can occur in all ages according to species, age, and size of the fish, the severity of the disease and environmental stresses can vary from acute to chronic (Evans et al. 2009). Perhaps some differences in the $\mathrm{LD}_{50}$ reported by different researchers are due to the difference in water temperature, the size of the fish and fish species; however, in the present study, attempts were made to make all the cases according to standard protocols. The study of Soltani and Tarahomi (2008) showed that $20 \%$ of the gram-positive cocci isolated from Fars province farms were L. garvieae. In the research of Soltani et al. (2015), the relative abundance of Lactococcosis was estimated to be $86.36 \%$ in Lorestan province and this ratio was $85.71 \%$ in Fars province. Due to the relative frequency in these two provinces, a significant number of farms are involved in lactococcosis.

The occurrence of Lactococcosis in rainbow trout farms occurs mainly from late June to early November. At the time of the onset of the disease, the temperature of the water was $17^{\circ} \mathrm{C}$, which increased the chances of getting the disease by increasing the temperature in the heating season and decreasing the water flow.

A recent study has reported that lactococcosis is developing in Chahar Mahal Bakhtiari and Kohkiluyeh and Boyerahmad provinces, and they have estimated the risk factors for the spread of this disease that include the weakness of health management, the lack of consideration of risk factors such as the presence of bacterial reservoirs near fish farms, the pollution of water to human and urban sewage, and the lack of timely vaccination
(Soltani et al. 2013). The results of Soltani et al. (2009) have shown that there is a lot of damage caused by lactococcosis in rainbow trout culture. On the other hand, given the fact that the disease is a zoonosis and the possibility of transmitting the disease to humans, it justifies the need for further attention. In such circumstances, the need to adopt practical and effective policies to combat the disease, such as vaccination and planning to eradicate the disease, felt more and more.

\section{Conclusion}

In general, according to current research, it can be concluded that the condition of lactococcosis in the studied area is not suitable, and despite the presence of disease, there is no proper action to control and prevent the disease. Unfortunately, isolated bacteria from the studied area have a very high severity compared to bacteria isolated from other regions of the country or other countries. Therefore, further investigation is needed to determine the cause of this difference and possibly in the design of the vaccine.

\begin{abstract}
Acknowledgements
This study was financed by Shahid Chamran University, Ahvaz, Iran. We would like to sincerely thank the experts of Aquatic Animal Health Laboratory, Faculty of Veterinary Medicine, Shahid Chamran University of Ahvaz
\end{abstract}

\section{Authors' contributions}

All authors read and approved the final manuscript.

\section{Funding}

This study was financially supported by the Shahid Chamran University, Ahvaz, Iran.

\section{Availability of data and materials}

All datasets generated and/or analyzed during the current study are available from the corresponding author on reasonable request.

\section{Consent for publication}

Not applicable.

\section{Competing interests}

The authors declare that they have no competing interests.

\section{Author details}

${ }^{1}$ Department of Clinical Sciences, Faculty of Veterinary Medicine, Shahid Chamran University of Ahvaz, Ahvaz, Iran. '2Department of Pathobiology, Faculty of Veterinary Medicine, Shahid Chamran University of Ahvaz, Ahvaz, Iran. ${ }^{3}$ Department of Basic Sciences, Faculty of Veterinary Medicine, Shahid Chamran University of Ahvaz, Ahvaz, Iran.

Received: 19 May 2019 Accepted: 21 August 2019

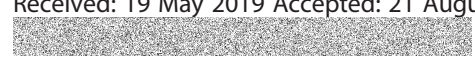

\section{References}

Akhlaghi M, Keshavarzi M. Occurrence of streptococcosis in rainbow trout fish farms in Fars Province. IRAN J VET RES. 2002;3:183-9.

Austin B, Austin DA. Bacterial fish pathogens, diseases of farmed and wild fish. Switzerland: Springer Praxis Publishing; 2007. p. 552.

Austin B, Austin DA. Bacterial fish pathogens, diseases of farmed and wild fish. 2nd Ed., Chichester, UK, Springer, Cham; 2016. P. 732.

Baños A, Ariza JJ, Nuñez C, Gil-Martínez L, García-López JD, Martínez-Buenoa M, Valdivia E. Effects of Enterococcus faecalis UGRA10 and the enterocin AS-48 against the fish pathogen Lactococcus garvieae. Studies in vitro and in vivo. Food Microbiol. 2019;77:69-77. 
Bauer AW, Kirby WM, Sherris JC, Turck M. Antibiotic susceptibility testing by a standardized single disk method. Am J Clin Pathol. 1966;45:493-6.

Chan JFW, Woo PCY, Teng JLL, Lau SKP, Leung SSM, Tam FCC, Yuen KY. Primary infective spondylodiscitis caused by Lactococcus garvieae and a review of human L. garvieae infections. Infection. 2011;39:259-64.

Chapela MJ, Ferreira M, Varela C, Arregui L, Garrido-Maestu A. Development of a multiplex real-time PCR method for early diagnosis of three bacterial diseases in fish: a real-case study in trout aquaculture. Aquaculture. 2018;496:255-61.

Chen SC, Liaw LL, Su HY, Ko SC, Wu CY, Chaung HC, Tsai YH, Yang KL, Chen YC, Chen TH, Lin GR, Cheng SY, Lin YD, Lee JL, Lai CC, Weng YJ, Chu SY. Lactococcus garvieae, a cause of disease in grey mullet, Mugil cephalus L., in Taiwan. J. Fish Dis. 2002;25:727-32.

Didinen B, Yardimci B, Onuk E, Metin S, Yildirim P. Naturally Lactococcus garvieae infection in rainbow trout (Oncorhyncus mykiss Walbaum, 1792): new histopathological observations, phenotypic and molecular identification. Rev Med Vet. 2014;165:12-9.

Eldar A, Ghittino C. Lactococcus garvieae and Streptococcus iniae infections in rainbow trout Oncorhynchus mykiss: similar, but different diseases. Dis Aquat Organ. 1999;36(3):227-31.

Evans JJ, Klesius PH, Shoemaker CA. First isolation and characterization of Lactococcus garvieae from Brazilian Nile tilapia, Oreochromis niloticus (L.), and pintado, Pseudoplathystoma corruscans (Spix \& Agassiz). J. Fish Dis. 2009:32:943-51.

Gauthier DT. Bacterial zoonoses of fishes: A review and appraisal of evidence for linkages between fish and human infections. Vet J. 2015;203:27-35.

Ghittino P, Prearo M. Report of Streptococcosis in rainbow trout (Oncorhynchus mykiss) in Italy: preliminary note. Bollettino Societa Italiana di Patalogia Ittica. 1992:8:4-9.

Kim JH, Go J, Cho CR, Kim Jl, Lee MS, Park SC. First report of human acute acalculous cholecystitis caused by the fish pathogen Lactococcus garvieae. J. Clin. Microbiol. 2013;51:712-4.

Kim SR, Lisa L, Suzuki S. Occurrence of tetracycline resistance genes tet(M) and tet(S) in bacteria from marine aquaculture sites. FEMS Microbiol Lett. 2004;237:147-56.

López C, Anguado-Urda M, Blanco MM, Gibello A, Cutuli MT, Lopez-Alonso V, Martín-Sánchez F, Fernández-Garayzábal JF. Lactococcus garvieae: a small bacteria and a big data world. Health Inf Sci Syst. 2015;3(Suppl 1):S5.

Meyburgh CM, Bragg RR, Boucher CE. Lactococcus garvieae: an emerging bacterial pathogen of fish. Dis Aquat Organ. 2017;123(1):67-79.

Prieta J. Lactococosis de la trucha arco iris. Med Vet. 1993:10:367-73.

Raissy M, Hashemi S, Roushan M, Jaafarian M, Momtaz H, Soltani M, Pirali Kheirabad E. Effects of essential oils of Satureja bachtiarica and Nigella sativa on the efficacy of lactococcosis vaccine in rainbow trout (Oncorhynchus mykiss). Iran J Vet Res. 2018;17:95-106.

Ravelo C, Magarinos B, Romalde JL, Toranzo AE. Convencional versus miniaturizad systems for the phenotypic characterization of Lactococcus garvieae strains. B Eur Assoc Fish Pat. 2001;21:136-44.

Reed $\mathrm{LJ}$, Muench $\mathrm{H}$. A simple method of estimating fifty per cent end points. Am J Hyg. 1938;27:493-7.

Roach JCM, Levett PN, Lavoie MC. Identification of Streptococcus iniae by commercial bacterial identification systems. J Microbiol Meth. 2006:67:20-6.

Sharifiyazdi H, Akhlaghi M, Tabatabaei M, Mostafavi Zadeh SM. Isolation and characterization of Lactococcus garvieae from diseased rainbow trout (Oncorhynchus mykiss, Walbaum) cultured in Iran. Iran J Vet Res. 2010;11:342-50.

Soltani M, Nikbakht G, Ebrahimzadeh H, Mousavi A. Epizootic outbreaks of Lactococcusis caused by Lactococcus garveae in farmed rainbow trout (Oncorhynchus mykiss) in Iran, vol. 28: B Eur Assoc Fish Pat; 2009. p. 207-12.

Soltani M, Nikbakht GH, Ebrahimzadeh HA, Ahmadzadeh N. Epizootic outbreaks of Lactococcus garvieae in farmed rainbow trout (Oncorhynchus mykiss) in Iran, vol. 28: B Eur Assoc Fish Pat; 2008. p. 209-14.

Soltani M, Pirali Khairabadi E, Ebrahimzadeh Mossavi HA, Mirzargar S, Shayan P. Genetic diversity of Streptococcus iniae; the cause of streptococcosis in farmed rainbow trout in Iran. IJVR. 2016;71:171-8.

Soltani M, Pirali Kheirabadi E, Taheri Mirghaed A, Zargar A, Mohamadian S, Sh R, Zakian M. Study on Streptococcosis and Lactococcosis outbreaks in rainbow trout farms in Fars and Lorestan Provinces. Vet Microbiol. 2015;30:49-58.

Soltani M, Pirali Kheirabadi E, Taherimirkahead A, Shafie SH, Mohamadian S, Roholahi SH. Molecular study of Streptococcosis/Lactococcosis distribution in farmed rainbow trout in Charmahal-va-Bakhteyari and Kohgiloyeh-vaBoyerahmad Provinces, Iran. Iran J Epidemiol. 2013;9(2):59-68.

Soltani M, Sh J, Sharifpour I. Streptococcosis caused by Streptococcus iniae in farmed rainbow trout (O. mykiss) in Iran: biophysical characteristics and pathogensis. B Eur Assoc Fish Pat. 2005;25:95-107.
Soltani M, Tarahomi M. Study of streptococcosis/lactococcosis in some farmed rainbow trout in Fars province, Iran. The first International Congress on Aquatic Animal Health Management and Diseases, Tehran, Iran. 2008.

Türe $\mathrm{M}$, Haliloğlu Hİ, Altuntaş C, Boran H, Kutlu I. Comparison of experimental susceptibility of rainbow trout (Oncorhynchus mykiss), turbot (Psetta maxima), black sea trout (Salmo trutta labrax) and sea bass (Dicentrarchus labrax) to Lactococcus garvieae. Turk J Fish Aquat Sc. 2014;14:507-13.

Vendrell D, Balcazar JL, Ruiz-Zarzuela I, de Blas I, Girones O, Muzquiz JL. Evaluation in rainbow trout (Oncorhynchus mykiss) of Ichtiovac-Lg, a vaccine against Lactococcus garvieae, Proceedings of the Sixth International Symposium on Fish Immunology. Nordic Society for Fish Immunology. Turku. Finland. 2004.

Vendrell D, Balcázar JL, Ruiz-Zarzuela I, de Blas I, Gironés O, Múzquiz JL. Lactococcus garvieae in fish: a review. Comp Immunol Microbiol Infect Dis. 2006:29:177-98.

Wang CYC, Shie HS, Chen SC, Huang JP. Lactococcus garvieae infections in humans: possible association with aquaculture outbreaks. Int J Clin Pract. 2007;61:68-73.

Woodman ME. Direct PCR of intact bacteria (colony PCR). Curr Protoc Microbiol. 2008:9:A.3D.1-6.

\section{Publisher's Note}

Springer Nature remains neutral with regard to jurisdictional claims in published maps and institutional affiliations.

\section{Ready to submit your research? Choose BMC and benefit from:}

- fast, convenient online submission

- thorough peer review by experienced researchers in your field

- rapid publication on acceptance

- support for research data, including large and complex data types

- gold Open Access which fosters wider collaboration and increased citations

- maximum visibility for your research: over $100 \mathrm{M}$ website views per year

At BMC, research is always in progress.

Learn more biomedcentral.com/submissions 